\title{
Lower Dietary Intake of Plant Protein Is Associated with Genetic Risk of Diabetes-Related Traits in Urban Asian Indian Adults
}

\author{
Sooad Alsulami ${ }^{1,2}$, Dhanasekaran Bodhini ${ }^{3}{ }^{(D)}$, Vasudevan Sudha ${ }^{4}$, Coimbatore Subramanian Shanthi Rani ${ }^{5}$, \\ Rajendra Pradeepa ${ }^{6}$, Ranjit Mohan Anjana ${ }^{6}$, Venkatesan Radha ${ }^{3}$, Julie A. Lovegrove ${ }^{1} \mathbb{D}$, Rajagopal Gayathri ${ }^{4}$, \\ Viswanathan Mohan ${ }^{6}$ (D) and Karani Santhanakrishnan Vimaleswaran $1,7, *$ (D)
}

check for updates

Citation: Alsulami, S.; Bodhini, D.; Sudha, V.; Shanthi Rani, C.S.; Pradeepa, R.; Anjana, R.M.; Radha, V.; Lovegrove, J.A.; Gayathri, R.; Mohan, V.; et al. Lower Dietary Intake of Plant Protein Is Associated with Genetic Risk of Diabetes-Related Traits in Urban Asian Indian Adults. Nutrients 2021, 13, 3064. https://doi.org/10.3390/ nu13093064

Academic Editors: Antonio Brunetti and Louise Deldicque

Received: 16 June 2021

Accepted: 27 August 2021

Published: 31 August 2021

Publisher's Note: MDPI stays neutral with regard to jurisdictional claims in published maps and institutional affiliations.

Copyright: (c) 2021 by the authors. Licensee MDPI, Basel, Switzerland. This article is an open access article distributed under the terms and conditions of the Creative Commons Attribution (CC BY) license (https:/ / creativecommons.org/licenses/by/ $4.0 /)$.
1 Hugh Sinclair Unit of Human Nutrition, Department of Food and Nutritional Sciences, University of Reading, Reading RG6 6DZ, UK; s.alsulami@student.reading.ac.uk (S.A.); j.a.lovegrove@reading.ac.uk (J.A.L.)

2 Department of Clinical Nutrition, Faculty of Applied Medical Sciences, King Abdulaziz University, Jeddah 21589, Saudi Arabia

3 Department of Molecular Genetics, Madras Diabetes Research Foundation, Chennai 603103, India; bodhinid@gmail.com (D.B.); radharv@yahoo.co.in (V.R.)

4 Department of Foods, Nutrition and Dietetics Research, Madras Diabetes Research Foundation, Chennai 600086, India; s2r_7@mdrf.in (V.S.); gayathri@mdrf.in (R.G.)

5 Department of Clinical Epidemiology, Madras Diabetes Research Foundation, Chennai 600086, India; kshan_rany@yahoo.com

6 Department of Diabetology, Madras Diabetes Research Foundation \& Dr. Mohan's Diabetes Specialities Centre, WHO Collaborating Centre for Non-Communicable Diseases Prevention and Control, ICMR Centre for Advanced Research on Diabetes, Gopalapuram, Chennai 600086, India; guhapradeepa@gmail.com (R.P.); dranjana@drmohans.com (R.M.A.);drmohans@diabetes.ind.in (V.M.)

7 The Institute for Food, Nutrition, and Health (IFNH), University of Reading, Reading RG6 6AP, UK

* Correspondence: v.karani@reading.ac.uk; Tel.: +44-(0)-118-378-8702

\begin{abstract}
The increasing prevalence of type 2 diabetes among South Asians is caused by a complex interplay between environmental and genetic factors. We aimed to examine the impact of dietary and genetic factors on metabolic traits in 1062 Asian Indians. Dietary assessment was performed using a validated semi-quantitative food frequency questionnaire. Seven single nucleotide polymorphisms (SNPs) from the Transcription factor 7-like 2 and fat mass and obesity-associated genes were used to construct two metabolic genetic risk scores (GRS): 7-SNP and 3-SNP GRSs. Both 7-SNP GRS and 3-SNP GRS were associated with a higher risk of T2D ( $p=0.0000134$ and 0.008 , respectively). The 3-SNP GRS was associated with higher waist circumference $(p=0.010)$, fasting plasma glucose (FPG) $(p=0.002)$ and glycated haemoglobin $(\mathrm{HbA1c})(p=0.000066)$. There were significant interactions between 3-SNP GRS and protein intake (\% of total energy intake) on FPG $\left(P_{\text {interaction }}=0.011\right)$ and $\mathrm{HbA1c}\left(\mathrm{P}_{\text {interaction }}=0.007\right)$, where among individuals with lower plant protein intake $(<39 \mathrm{~g} /$ day $)$ and those with $>1$ risk allele had higher FPG $(p=0.001)$ and HbA1c $(p=0.00006)$ than individuals with $\leq 1$ risk allele. Our findings suggest that lower plant protein intake may be a contributor to the increased ethnic susceptibility to diabetes described in Asian Indians. Randomised clinical trials with increased plant protein in the diets of this population are needed to see whether the reduction of diabetes risk occurs in individuals with prediabetes.
\end{abstract}

Keywords: genetic risk score; metabolic traits; urban Asian Indian; dietary protein intake; gene-diet interaction; T2D

\section{Introduction}

South Asian populations have a 50\% higher risk of type 2 diabetes (T2D) than other populations [1,2] and this has significant implications, as patients with T2D have a $2-4$ times increased risk of cardiovascular diseases [1]. The Asian Indian population have a unique phenotype characterised by abdominal and truncal adiposity, as indicated by larger waist 
to hip ratios and waist circumference (WC), higher concentrations of plasma insulin, greater insulin resistance, impaired function of pancreatic $\beta$-cell and a genetic susceptibility to diabetes, which ultimately leads to significantly increased diabetes risk [3-5]. The burden of T2D is increasing globally, with India being a major contributor to the worldwide burden [6]. The number of diabetic individuals in India rose from 26.0 million in 1990 to 65.0 million in 2016 [7].

The increasing prevalence of T2D among Asian Indians is caused by a complex interplay between environmental and genetic factors, including urbanisation, which plays a large role [8-10]. Urbanisation in India is associated with increased consumption of processed foods and dietary fats, decreased level of physical activity and increased mental stress, amplifying the effects of abdominal obesity and insulin resistance [4,5,11]. Furthermore, the urban areas in India reported higher intake of protein from pulses and animal sources (including meat, fish, eggs and milk) than rural areas [12]. Several large longitudinal studies showed that the intake of animal protein was significantly associated with the risk of T2D [13-17]. In the context of rapid urbanisation and nutrition transition, interactions between Westernised diet, lifestyle and genetic factors have further escalated T2D prevalence in Asia $[18,19]$. In South Asians, several single nucleotide polymorphisms (SNPs) have been associated with adiposity [20-23], insulin resistance [24], pancreatic $\beta$-cell function $[20,25,26]$ and T2D $[20,22,23,26,27]$. The fat mass and obesity-associated (FTO) gene has been recognised as one of the strongest obesity-related genes. The FTO SNPs, rs1588413, rs9939609 and rs8050136, have been shown to increase obesity risk by $1.27,1.15$ and 2.06 times among Indians, respectively [22,28]. Studies have reported strong associations of the Transcription factor 7-like 2 (TCF7L2) SNPs, rs7903146 and rs12255372, with T2D risk in Asian Indians [29-31]. To date, evidence has identified 243 genetic loci to be associated with T2D risk in South Asians, East Asians, Europeans, African Americans and Hispanics [32-35]. Single genetic variants have only a small to moderate effect on disease risk, thus combining effects of several SNPs into a genetic risk score (GRS) is required for better detection of individuals with high risk of diabetes [36].

Genome-wide association studies (GWAS) have discovered a large number of genetic variants associated with metabolic diseases and related traits; however, these SNPs describe only a small proportion of estimated heritability. Risk prediction of metabolic diseases is complicated by interactions between dietary and genetic factors, which may partly explain the missing heritability of diseases [37]. Investigating gene-diet interaction is important in understanding pathophysiology of metabolic diseases, which can lead to the development of 'personalised' nutrition focusing on tailoring dietary interventions according to individual genotypic makeup to prevent and treat metabolic diseases [38,39]. The effect of genetic factors on metabolic traits have been shown to be modified by dietary intake in several populations [40-44]. However, studies investigating GRS-diet interaction in the Indian population are still sparse. To help fill this gap in knowledge, we assessed the combined effect of seven genetic variants, as a GRS, on T2D and metabolic traits, and the extent to which dietary intake can influence these genetic associations among 1062 urban Asian Indians.

\section{Methods}

\subsection{Study Participants}

The present study included individuals from the urban area of the Chennai Urban Rural Epidemiology Study (CURES), which is a cross-sectional epidemiological study performed on a representative sample of Chennai city (formerly Madras) in southern India. The design and procedures of the CURES have been explained in detail previously [45]. In phase 1, a total of 26,001 adult subjects, of which 1529 were 'self-reported' or 'known diabetic' individuals, were recruited using a method of systematic random sampling. In phase 2, diabetic individuals were invited to the study centre for further investigation, of whom 1382 responded. In phase 3, every 10th individual of the total sample ( $n=26,001$ subjects), excluding individuals with self-reported diabetes, were 
screened using an oral glucose tolerance test (OGTT). Individuals with fasting plasma glucose (FPG) $<5.6 \mathrm{mmol} / \mathrm{L}(100 \mathrm{mg} / \mathrm{dL})$ and $2 \mathrm{~h}$ plasma glucose value of $7.8 \mathrm{mmol} / \mathrm{L}$ $(140 \mathrm{mg} / \mathrm{dL})$ were defined as having normal glucose tolerance (NGT) [46]. Those who had $2 \mathrm{~h}$ plasma glucose value of $11.1 \mathrm{mmol} / \mathrm{L}(200 \mathrm{mg} / \mathrm{dL})$ were categorised as 'newly detected diabetic subjects' $(n=222)$ (Figure S1). The total sample of present study is 1062 individuals; the NGT individuals were chosen from Phase $3(n=496)$ and T2D individuals were chosen from Phase 2 and Phase 3 of the CURES $(n=566)$. The study was approved by the Madras Diabetes Research Foundation Institutional Ethics Committee and written informed consent was obtained from all study participants.

\subsection{Anthropometric and Biochemical Measurements}

Anthropometric variables including WC, weight and height were measured using standardised methods. The body mass index (BMI) was calculated with the formula of weight (in kilograms) divided by the square of height (in metres), with obesity being defined as BMI $\geq 25$ according to World Health Organisation Asia Pacific Guidelines for Asians [47].

Biochemical tests were carried out using a Hitachi-912 Auto Analyzer (Hitachi, Mannheim, Germany), with kits provided by Roche Diagnostics (Mannheim). Glycated haemoglobin ( $\mathrm{HbA1c}$ ) was measured using high-performance liquid chromatography on a Variant machine (Bio-Rad, Hercules, CA, USA). FPG and serum insulin were measured using glucose oxidase-peroxidase and an enzyme-linked immunosorbent assay (Dako, Glostrup, Denmark), respectively.

\subsection{Dietary Assessments}

Participants' habitual food intake over the previous year was measured using a validated semi-quantitative food frequency questionnaire (FFQ) administered by an interviewer [48]. The FFQ consists of 222 food items and individuals were asked to estimate the usual portion size and frequency (number of times per day, week, month or year/never) of food items listed in the FFQ. Participants were shown common household measures and photographic atlas of different sizes of fruits to help them in estimating portion sizes. The $\mathrm{EpiNu}^{\circledR}$ software was used to analyse the recorded data and estimate the intake of energy and macronutrients. The reported intake of various food groups was also estimated. The EpiNu software also provided the source of protein from various food groups. Animal protein intake was summed up using protein intake (g/day from FFQ) from animal food groups such as meat, poultry, fish, egg and dairy products. Similarly, plant protein intake was estimated from food groups such as cereals, millets, pulses and legumes, tubers, nuts, oilseeds, vegetables and fruits. In addition, dairy protein was estimated separately using dairy products such as milk products and fermented and unfermented milk.

\subsection{SNP Selection and GRS Construction}

A total of 7 metabolic disease-associated SNPs which have been extensively studied in various populations, including Asian Indians, were selected for the study [20-27,29]. The selected SNPs included TCF7L2 SNPs, rs12255372 and rs7903146, and FTO SNPs, rs8050136, rs918031, rs1588413, rs7193144 and rs1076023. Details regarding these SNPs are summarised in Table S1. Each SNP was coded with the expected number of metabolic diseases-associated risk alleles. Consistent with previous studies [41,49,50], we used an unweighted method to construct the GRSs by summing the number of risk alleles of each SNP for each participant. The seven SNPs were used to generate a 7-SNP GRS that ranges from 1 to 11 risk alleles. The GRS was divided into 2 categories according to the median number of risk alleles: "GRS $<6$ risk alleles" and "GRS $\geq 6$ risk alleles", indicating individuals with lower and higher risk alleles of the SNPs, respectively. In addition, we constructed a GRS of 3 SNPs (FTOSNP rs8050136 and TCF7L2SNPs rs12255372 and rs7903146) that have shown consistent associations with metabolic disease-related outcomes across various ethnicities, including Asians [51-54]. The 3-SNP GRS ranges from 
0 to 6 risk alleles and was divided into 2 categories according to the median number of risk alleles: "GRS $\leq 1$ risk allele" group and "GRS $>1$ risk allele" group, indicating individuals with lower and higher risk alleles of the SNPs, respectively.

\subsection{Genotyping}

The genotyping methodologies have been previously published [22,30]. The phenolchloroform technique was used to extract DNA from whole blood. Genotyping was performed using restriction fragment length polymorphism and confirmed by direct sequencing in which duplicate samples $(n=200 ; 20 \%)$ were genotyped with $100 \%$ concordance, suggesting high genotyping accuracy.

\subsection{Statistical Analysis}

Descriptive statistics of continuous variables are provided as means with standard deviations (SDs) and compared between T2D and controls using an independent sample $t$-test. Normality tests were performed and variables with no-normal distribution were log transformed. For each individual SNP, genotype counts were assessed for Hardy-Weinberg equilibrium (HWE) using a goodness-of-fit chi-square test. As shown in Table S1, all SNPs were in HWE ( $p>0.092$, for all comparisons). General linear models were utilised to analyse the main associations of the GRS with metabolic traits. Interactions of the GRS with dietary intake were investigated by including the interaction term (GRS*dietary intake) in the models. Furthermore, significant interactions with protein intake were analysed in more depth according to dietary sources of protein (animal and plant protein), where individuals were classified into two groups according to the sample median intake of plant ( $39 \mathrm{~g} /$ day) and animal protein ( $19 \mathrm{~g} /$ day): below and above median groups. Individuals who consumed below the median were categorised as those who had lower intakes of plant and animal protein, respectively, whereas individuals who consumed above the median were categorised as those who had higher intakes of plant and animal protein, respectively. Dietary intakes as percentage of total energy intake (TEI) included intake of protein, carbohydrate and fat. Models were adjusted for sex, age, T2D, anti-diabetic medication and BMI (when BMI is not an outcome). Furthermore, as part of the sensitivity analysis, we further adjusted for duration of diabetes, dairy protein intake, physical activity level, smoking, alcohol consumption and fibre intake. Statistical analyses were carried out using Statistical Package for the Social Sciences (SPSS) software (version 24; SPSS Inc., Chicago, IL, USA), with a significance level of 0.05 .

\section{Results}

\subsection{Characteristics of Study Participants}

As shown in Table 1, individuals with T2D were significantly older and had higher BMI, WC, HbA1c, FPG and insulin, compared to individuals with NGT ( $p<0.05$ for all). Moreover, diabetic individuals had significantly higher intakes of total protein and carbohydrate than individuals with NGT ( $p<0.05$ for all). 
Table 1. Characteristics of study participants.

\begin{tabular}{|c|c|c|c|c|c|c|c|}
\hline & \multicolumn{2}{|c|}{ Total } & \multicolumn{2}{|c|}{ NGT Controls } & \multicolumn{2}{|c|}{ T2D Cases } & \multirow{2}{*}{$p$ Value } \\
\hline & $n$ & & $n$ & & $n$ & & \\
\hline \multicolumn{8}{|l|}{ Sex } \\
\hline Men (\%) & 591 & 56 & 278 & 56 & 313 & 55 & $0.807^{* * *}$ \\
\hline Women (\%) & 471 & 44 & 218 & 44 & 253 & 45 & \\
\hline Age (years) & 1062 & $45 \pm 12$ & 496 & $38 \pm 10$ & 566 & $51 \pm 11$ & $1.160 \times 10^{-71 *}$ \\
\hline Diabetes duration & - & - & - & - & 566 & $5.20 \pm 5.29$ & - \\
\hline Anti-diabetic medication & - & - & - & - & 164 & $15.4 \%$ & - \\
\hline BMI $\left(\mathrm{kg} / \mathrm{m}^{2}\right)$ & 1061 & $24.6 \pm 4.56$ & 496 & $23.5 \pm 4.64$ & 565 & $25.5 \pm 4.30$ & $1.480 \times 10^{-12 *}$ \\
\hline $\mathrm{WC}(\mathrm{cm})$ & 1022 & $87 \pm 12$ & 479 & $83 \pm 12$ & 543 & $91 \pm 10$ & $5.692 \times 10^{-33 *}$ \\
\hline HBA1C (\%) & 1056 & $7.3 \pm 2.4$ & 492 & $5.6 \pm 0.47$ & 564 & $8.8 \pm 2.4$ & $1.480 \times 10^{-14 *}$ \\
\hline $\mathrm{FPG}(\mathrm{mg} / \mathrm{dL})$ & 1060 & $126 \pm 64$ & 495 & $85 \pm 8$ & 565 & $162 \pm 69$ & $1.392 \times 10^{-127 *}$ \\
\hline Fasting Insulin $(\mu \mathrm{IU} / \mathrm{mL})$ & 699 & $9 \pm 7$ & 448 & $8 \pm 6$ & 251 & $12 \pm 7$ & $6.386 \times 10^{-101 *}$ \\
\hline Energy (kcal/day) & 1062 & $2536 \pm 805$ & 496 & $2685 \pm 708$ & 566 & $2406 \pm 861$ & $8.773 \times 10^{-9 *}$ \\
\hline Protein $(\%)$ & 1062 & $11 \pm 1$ & 496 & $11.27 \pm 1.17$ & 566 & $11.45 \pm 1.23$ & 0.014 * \\
\hline Animal protein (g/day) & 1062 & $22 \pm 12$ & 496 & $25 \pm 13$ & 566 & $19 \pm 11$ & $3.787 \times 10^{-14 *}$ \\
\hline Plant protein (g/day) & 1062 & $40 \pm 14$ & 496 & $42 \pm 15$ & 566 & $39 \pm 13$ & $0.006 *$ \\
\hline Fat $(\%)$ & 1062 & $23 \pm 5$ & 496 & $24 \pm 5$ & 566 & $23 \pm 5$ & $0.113 *$ \\
\hline Carbohydrate (\%) & 1062 & $65 \pm 6$ & 496 & $64 \pm 6$ & 566 & $65 \pm 6$ & $0.003 *$ \\
\hline Dietary fibre (g) & 1062 & $32 \pm 11$ & 496 & $32 \pm 10$ & 566 & $31 \pm 12$ & $0.150 *$ \\
\hline Total SFA (g) & 1062 & $24 \pm 10$ & 496 & $27 \pm 10$ & 566 & $22 \pm 10$ & $2.295 \times 10^{-12 *}$ \\
\hline Total MUFA (g) & 1062 & $20 \pm 8$ & 496 & $21 \pm 8$ & 566 & $18 \pm 8$ & $3.943 \times 10^{-9 *}$ \\
\hline Total PUFA (g) & 1062 & $18 \pm 10$ & 496 & $19 \pm 9$ & 566 & $18 \pm 10$ & 0.184 * \\
\hline \multicolumn{8}{|l|}{ Physical activity level } \\
\hline Sedentary & 695 & $71 \%$ & 335 & $73 \%$ & 360 & $70 \%$ & \\
\hline Moderate & 223 & $23 \%$ & 110 & $24 \%$ & 113 & $22 \%$ & $0.001^{* *}$ \\
\hline Vigorously active & 58 & $6 \%$ & 13 & $3 \%$ & 45 & $8 \%$ & \\
\hline \multicolumn{8}{|l|}{ Smoking } \\
\hline Non-smokers & 865 & $81.5 \%$ & 396 & $79.8 \%$ & 469 & $82.9 \%$ & $0.206^{* *}$ \\
\hline Smokers & 197 & $18.5 \%$ & 100 & $20.2 \%$ & 97 & $17.1 \%$ & \\
\hline \multicolumn{8}{|l|}{ Alcohol consumption } \\
\hline Non-alcoholics & 793 & $74.7 \%$ & 358 & $72.2 \%$ & 435 & $76.9 \%$ & $0.080 * *$ \\
\hline Alcoholics & 269 & $25.3 \%$ & 138 & $27.8 \%$ & 131 & $23.1 \%$ & \\
\hline
\end{tabular}

Data presented as Mean $\pm \mathrm{SD}$. ${ }^{*} p$ values are for the mean differences between controls and T2D cases using an independent sample $t$-test. ** $p$ values are from the Chi-squared test. Frequency of men and women between controls and cases was compared using a chi-square test. Abbreviations: NGT, normal glucose tolerance; T2D, type 2 diabetes; BMI, body mass index; WC, waist circumference; HbA1c, glycated haemoglobin; FPG, fasting plasma glucose; SFA, saturated fatty acids; MUFA, monounsaturated fatty acids; PUFA, polyunsaturated fatty acids.

\subsection{Association between Metabolic GRS and Metabolic Traits}

After adjusting for the potential confounders there were no significant associations between the 7-SNP GRS and metabolic traits (Table 2).

Table 2. Associations of 7-SNP and 3-SNP GRS and with metabolic traits.

\begin{tabular}{|c|c|c|c|c|c|c|c|c|c|c|}
\hline & \multicolumn{5}{|c|}{ 7-SNP GRS } & \multicolumn{5}{|c|}{ 3-SNP GRS } \\
\hline & $n$ & GRS $<6$ & $n$ & GRS $\geq 6$ & $p$ Value & $n$ & GRS $\leq 1$ & $n$ & GRS $>1$ & $p$ Value * \\
\hline $\mathrm{BMI}\left(\mathrm{kg} / \mathrm{m}^{2}\right)$ & 526 & $24.5 \pm 0.2$ & 535 & $24.7 \pm 0.2$ & 0.572 & 645 & $24.7 \pm 0.2$ & 416 & $24.5 \pm 0.2$ & 0.572 \\
\hline$W C(\mathrm{~cm})$ & 508 & $86.7 \pm 0.5$ & 514 & $87.4 \pm 0.5$ & 0.668 & 620 & $87.0 \pm 0.47$ & 402 & $88.0 \pm 0.57$ & 0.010 \\
\hline HBA1C (\%) & 524 & $7.1 \pm 0.1$ & 532 & $7.4 \pm 0.1$ & 0.935 & 640 & $7.0 \pm 0.1$ & 416 & $7.7 \pm 0.1$ & 0.000066 \\
\hline FPG (mg/dL) & 526 & $119.9 \pm 2.6$ & 534 & $131.6 \pm 2.9$ & 0.181 & 644 & $120.0 \pm 2.35$ & 416 & $135.0 \pm 3.39$ & 0.002 \\
\hline $\begin{array}{l}\text { Fasting insulin } \\
\qquad(\mu \mathrm{IU} / \mathrm{mL})\end{array}$ & 373 & $9.5 \pm 0.4$ & 326 & $9.4 \pm 0.3$ & 0.767 & 419 & $10.0 \pm 0.36$ & 280 & $9.0 \pm 0.33$ & 0.171 \\
\hline
\end{tabular}

Data are Mean \pm standard error of the mean. ${ }^{*} p$ values adjusted for sex, age, T2D, anti-diabetic medication and additionally for BMI, when BMI is not an outcome. The analysis was carried out using log-transformed variables. Abbreviations: GRS, genetic risk score; BMI, body mass index; WC, waist circumference; HbA1c, glycated haemoglobin; FPG, fasting plasma glucose.

In the 3-SNP GRS analysis, significant associations were found with WC $(p=0.010)$, FPG $(p=0.002)$ and $\operatorname{HbA} 1 \mathrm{c}(p=0.000066)$, where individuals with $>1$ risk allele had higher 
WC, FPG and HbA1c compared to individuals with $\leq 1$ risk allele (Table 2). Both 7-SNP GRS and 3-SNP GRS were associated with a higher risk of T2D $(p=0.0000134$ and 0.008 , respectively) (Table 3).

Table 3. Association of 7-SNP and 3-SNP GRSs with T2D.

\begin{tabular}{ccccc}
\hline \multirow{2}{*}{ GRS } & \multirow{2}{*}{ OR } & \multicolumn{2}{c}{ 95\% CI for OR } & \multirow{2}{*}{$p$ Value * } \\
\cline { 3 - 4 } & & Lower & Upper & \\
\hline 7-SNP GRS & 2.083 & 1.496 & 2.898 & 0.0000134 \\
3-SNP GRS & 1.559 & 1.121 & 2.170 & 0.008 \\
\hline
\end{tabular}

* $p$ values were obtained from the logistic regression models adjusted for sex, age, anti-diabetic medication and BMI. Abbreviations: GRS, genetic risk score; SNP, single nucleotide polymorphism; T2D, type 2 diabetes; OR, odds ratio; $\mathrm{CI}$, confidence interval; $\mathrm{BMI}$, body mass index.

\subsection{Interaction of 7-SNP and 3-SNP GRSs with Dietary Factors on Metabolic Traits}

As shown in Table 4, there were significant interactions between the 3-SNP GRS and total protein intake $\left(\%\right.$ of TEI) on FPG $\left(P_{\text {interaction }}=0.011\right)$ and HbA1c $\left(P_{\text {interaction }}=0.007\right)$. Among individuals with lower intake of plant protein $(<39 \mathrm{~g} /$ day $)$, those with $>1$ risk allele had higher FPG $(p=0.001)$ and HbA1c $(p=0.00006)$ than individuals with $\leq 1$ risk allele (Figure 1). Furthermore, among individuals with higher intake of animal protein $(>19 \mathrm{~g} /$ day $)$, those with $>1$ risk allele had higher FPG $(p=0.008)$ and HbA1c $(p=0.001)$ than individuals with $\leq 1$ risk allele (Figure S2). None of the interactions were significant between the 7-SNP GRS and dietary intakes on metabolic traits except for the interactions between 7-SNP GRS and protein intake on HbA1c $\left(P_{\text {interaction }}=0.032\right)$, and 7-SNP GRS and carbohydrate intake $\left(P_{\text {interaction }}=0.04\right)$ on fasting insulin. However, these interactions were not significant after stratifying based on animal and plant protein.

Table 4. Interactions of 7-SNP and 3-SNP GRSs with dietary factors on metabolic traits.

\begin{tabular}{|c|c|c|c|c|c|c|}
\hline & \multicolumn{3}{|c|}{ 7-SNP GRS } & \multicolumn{3}{|c|}{ 3-SNP GRS } \\
\hline & Protein & Fat & Carbohydrate & Protein & Fat & Carbohydrate \\
\hline & (\% of TEI) & (\% of TEI) & (\% of TEI) & (\% of TEI) & (\% of TEI) & (\% of TEI) \\
\hline BMI $\left(\mathrm{kg} / \mathrm{m}^{2}\right)$ & 0.176 & 0.388 & 0.195 & 0.36 & 0.653 & 0.805 \\
\hline$W C(\mathrm{~cm})$ & 0.852 & 0.786 & 0.892 & 0.638 & 0.958 & 0.914 \\
\hline HBA1C (\%) & 0.032 & 0.629 & 0.618 & 0.007 & 0.677 & 0.756 \\
\hline FPG (mg/dL) & 0.249 & 0.489 & 0.507 & 0.011 & 0.367 & 0.231 \\
\hline Fasting insulin $(\mu \mathrm{I} U / \mathrm{mL})$ & 0.952 & 0.085 & 0.04 & 0.299 & 0.567 & 0.999 \\
\hline T2D & 0.956 & 0.214 & 0.152 & 0.764 & 0.508 & 0.365 \\
\hline
\end{tabular}

Data are $\mathrm{P}_{\text {interaction }}$ values adjusted for sex, age, T2D, antidiabetic medications and additionally for BMI, when BMI is not an outcome. The analysis was carried out using log-transformed variables. Abbreviations: GRS, genetic risk score; TEI, total energy intake; BMI, body mass index; WC, waist circumference; HbA1c, glycated haemoglobin; FPG, fasting plasma glucose; T2D, type 2 diabetes. 
(a)

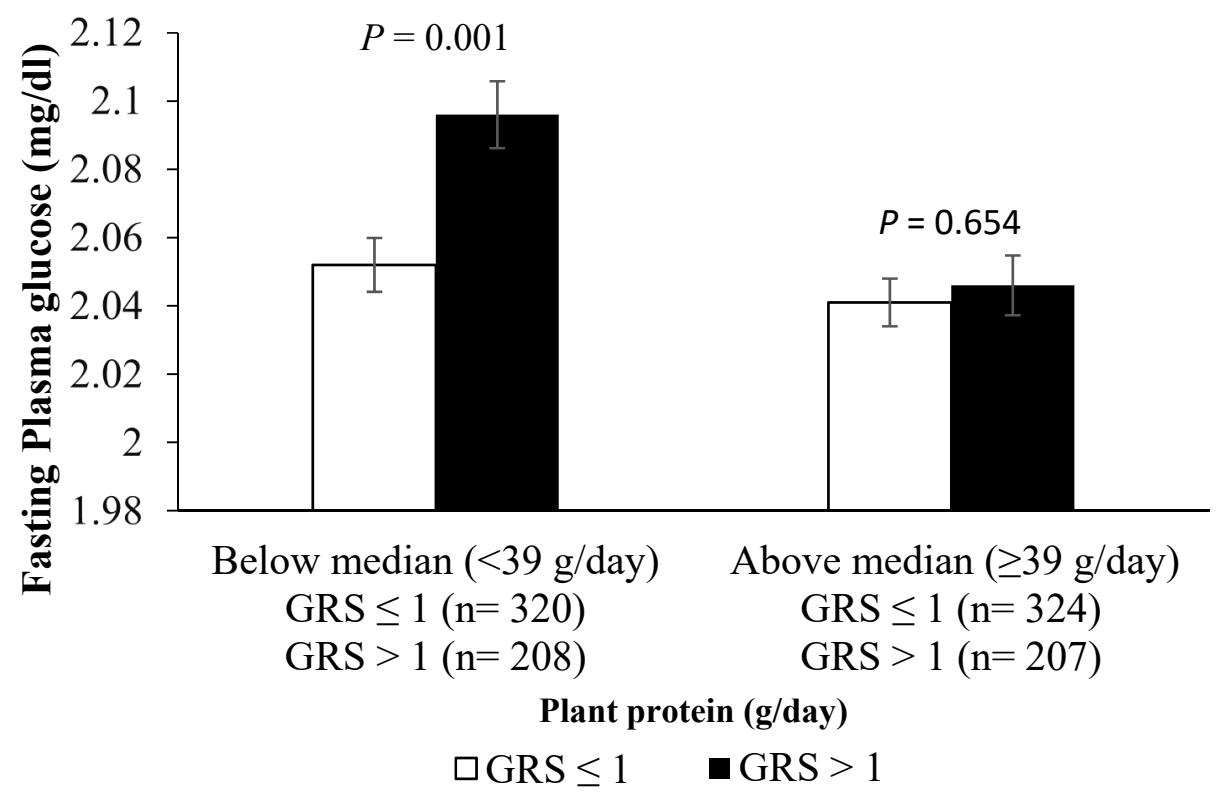

(b)

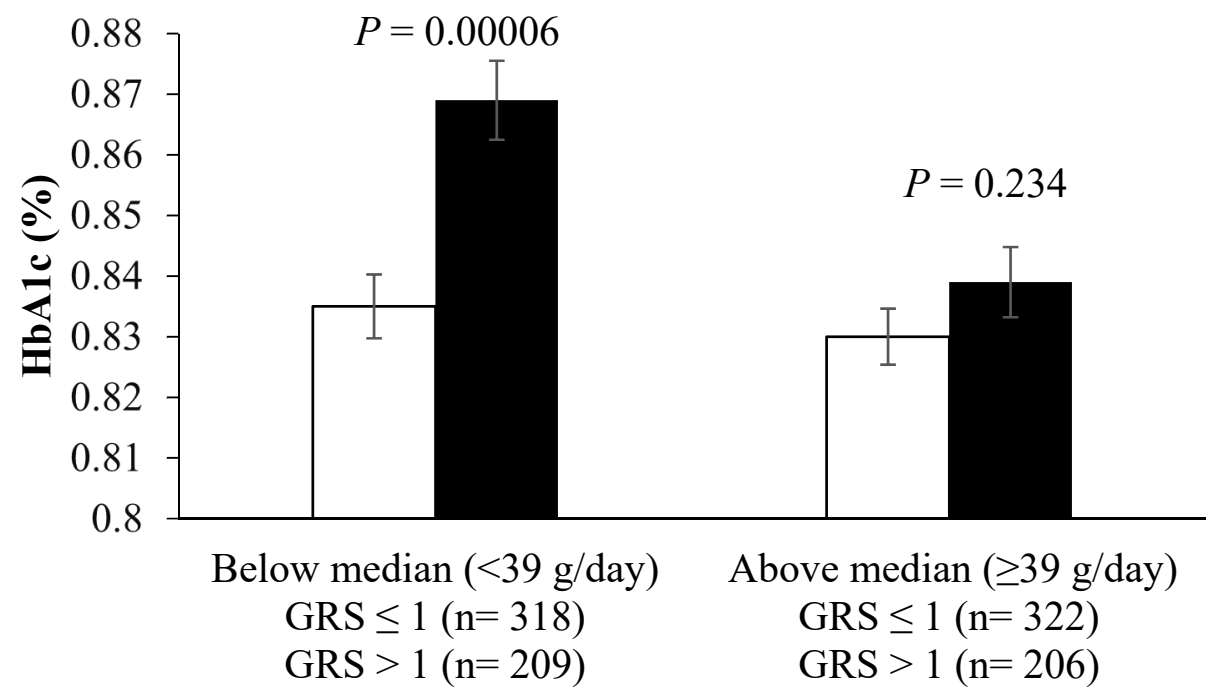

Plant protein (g/day)

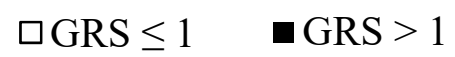

Figure 1. Interaction between 3-SNP GRS and plant protein intake on fasting plasma glucose and glycated haemoglobin. White bars refer to individuals with GRS $\leq 1$ risk allele; the black bars refer to individuals with GRS $>1$ risk allele. (a) Individuals with $>1$ risk allele had a significantly higher FPG compared to those with $\leq 1$ risk allele, among those with lower intake of plant protein ( $<39 \mathrm{~g} /$ day) $(p=0.001)$. (b) Individuals with $>1$ risk allele had a significantly higher HbA1c compared to those with $\leq 1$ risk allele, among those with lower intake of plant protein ( $<39 \mathrm{~g} /$ day $)(p=0.00006)$. $p$ values were adjusted for age, sex, T2D, BMI, anti-diabetic medication, total fat intake (\%) and TEI. Abbreviations: GRS, genetic risk score; FPG, fasting plasma glucose; HbA1c, glycated haemoglobin; TEI, total energy intake. 


\subsection{Sensitivity Analyses}

We subjected our regression results to a wide range of robustness checks. First, we adjusted for duration of diabetes, and the association of 3-SNP GRS with HbA1c and FPG ( $p=0.010$ and 0.040 , respectively) and the interaction of 3-SNP GRS with protein intake (\%) ( $P_{\text {interaction }}=0.025$ and 0.019 for HbA1c and FPG, respectively) were still significant. Second, we excluded individuals with diabetes, and this resulted in a small sample size of 496 NGTs. However, a significant association of 3-SNP GRS with $\mathrm{HbA1c}(p=0.012)$ was still observed, but none of the interactions were statistically significant $(p=0.126$ and 0.405 for $\mathrm{HbA} 1 \mathrm{c}$ and FPG, respectively). Third, given the association between dietary fat intake and T2D traits, we adjusted for total dietary fat intake and found that the interaction of 3-SNP GRS with protein intake $(\%)\left(\mathrm{P}_{\text {interaction }}=0.007\right.$ and 0.009 for $\mathrm{HbA} 1 \mathrm{c}$ and FPG, respectively) was still significant. Fourth, we tested for the interaction between 3-SNP GRS and dairy protein intake to see if the interactions with the animal protein intake were driven by the intake of dairy protein. We found that the interactions between 3-SNP GRS and dairy protein intake were not statistically significant $\left(P_{\text {interaction }}=0.439\right.$ and 0.597 for HbA1c and FPG, respectively), suggesting that dairy protein intake is unlikely to confound the GRS-animal protein intake interaction on diabetes traits. Fifth, in addition to the aforementioned factors, we adjusted for other possible confounders such as physical activity level, smoking, alcohol consumption and fibre intake, and found that the interactions between the 3-SNP GRS and protein intake on $\mathrm{HbA} 1 \mathrm{c}$ and FPG were still significant $\left(\mathrm{P}_{\text {interaction }}=0.009\right.$ and 0.008 , on $\mathrm{HbA1c}$ and FPG, respectively).

\section{Discussion}

The current research provides evidence for the GRS-protein intake interaction on T2D-related traits in Asian Indians. We found that individuals with $>1$ risk allele had higher FPG and HbA1c levels than those with $\leq 1$ risk allele among individuals with lower intake of plant protein ( $<39 \mathrm{~g} /$ day). Given that the prevalence of obesity, high FPG and T2D has increased in India from 1990 to 2016 [55], our findings are of importance in terms of public health. Our study suggests that increasing the intake of plant protein might be an effective strategy towards better management of blood glucose levels, especially in Asian Indians with a higher genetic susceptibility for T2D.

In the present study, the 3-SNP GRS was associated with higher WC, which is in accordance with the findings in 7067 individuals from the Indian Migrant Study where a combined risk score of eight variants was observed to be nominally associated with higher WC ( $p=0.02)$ [56]. The 3-SNP GRS was also associated with FPG and HbA1c, where individuals with higher GRS had higher FPG and HbA1c. Similarly, a large GWAS in 159,940 individuals of African, South Asian, East Asian and European ancestries identified 60 genetic variants influencing HbA1c [57], including SNPs located in the FTO and TCF7L2 genes. An association of 8-SNP GRS with T2D was found in a case-control study of 5,148 Indians (including 1808 individuals with T2D and 1549 controls) from in and around Pune in western India [25]. A case-control study of 3357 Indian adults (including 2486 individuals with T2D and 2678 controls) also found that individuals with a higher GRS, derived from 32 SNPs, were at a higher T2D risk compared to those with lower GRS [58]. The EpiDREAM prospective cohort study ( $n=15,466$ individuals) has shown that South Asians might have a greater genetic load for T2D than Latinos and Europeans [59]. If our study findings are confirmed in larger cohorts, our 3-SNP GRS might serve as a diagnostic marker for investigating the cumulative effect of SNPs on diabetes-related traits and identifying Asian Indians with a high genetic risk of T2D.

Increasing evidence has shown that certain dietary factors might interact with genetic susceptibility in relation to the risk of diabetes and related traits [40-42,44,60]. In our study, individuals with higher 3-SNP GRS had higher fasting glucose and $\mathrm{HbA1c}$ concentrations than individuals with lower GRS among individuals with lower intake of plant protein. The results of the current analysis are in agreement with a recent study among Southeast Asian women $(n=110)$ showing significant interactions between a 15-SNP GRS and total 
protein intake. The study found that consuming a low protein diet $(13.51 \pm 1.18 \%$ of TEI) was associated with lower WC and triacylglycerol concentrations, particularly in individuals with high genetic risk [60]. Moreover, significant interactions of the FTO SNPs $($ rs8044769 $(\mathrm{C}>\mathrm{T}), \mathrm{rs} 3751812(\mathrm{G}>\mathrm{T})$ and $\mathrm{rs} 8050136(\mathrm{~A}>\mathrm{C})$ ) with protein intake on blood glucose were observed in 819 Polish adults, where higher protein intake ( $>18 \%$ of TEI) was associated with higher blood glucose in individuals with the TT genotype of rs8044769, CC genotype of rs8050136 and GG genotype of rs3751812 [61]. However, the effect of protein sources was not analysed in the abovementioned studies, thus a direct comparison between these studies and our findings cannot be performed. In contrast to our study, a large prospective case-cohort study from eight European countries $(n=21,900)$ found no significant interactions between intake of protein and metabolic GRSs on T2D [62]. Similarly, no interaction was found between protein intake and a 10-SNP GRS on T2D risk among 8842 Korean adults [42]. These discrepancies in the findings might be due to differences in ethnicity, dietary assessments, dietary patterns, relative proportions of different macronutrients, protein sources, sample sizes and GRS construction methods; hence, larger studies in multiple ethnic groups are needed to confirm the GRS-protein intake interactions.

Previous studies have examined the relationship between protein intake and T2D in South Indians. A cross-sectional study of 900 urban South Indians from Chennai demonstrated that individuals with known T2D had significantly higher protein intake $(15.9 \%)$ than controls (14\%) [63]. Another study in Asian Indians from different parts of India reported similar findings, where diabetic individuals $(n=385)$ had higher protein intake $(14 \%)$ than controls $(12 \%)(n=409)$ [64]. A cohort including 146 Asian Indians living in San Francisco found that individuals were at increased T2D risk when the protein intake was high. The same study also reported that the intake of animal protein $(32 \pm 15 \mathrm{~g} /$ day $)$ was more likely to be associated with diabetes risk $(p=0.07)$ in comparison with the intake of vegetable protein ( $38 \pm 8 \mathrm{~g} /$ day; $p=0.26$ ) [65]. Even though consuming diets high in protein has been one of the most popular strategies for losing weight and the management of overweight and obesity [66-68], the health impacts of diets high in protein on T2D are inconsistent. Higher animal protein intake, but not plant protein, showed significant association with a higher risk of T2D in 38,094 individuals (median intake of animal protein $=62 \mathrm{~g} /$ day; 10 -year follow-up period) from the European Prospective Investigation into Cancer and Nutrition-Netherlands (EPIC-NL) study [13], and in 37,309 women from the US (median intake of total meat in the highest quintiles $=53.5$ serving/day; 8.8 year follow-up period) from the Women's Health Study [14]. Moreover, a large case-cohort study including 28,557 European individuals reported that higher animal protein intake was associated with higher incidence of T2D (per $10 \mathrm{~g}: 1.05$ (1.02-1.08), $\mathrm{P}_{\text {trend }}=0.001$ ) over an average follow-up period of 12 years [16]. Furthermore, the higher intake of animal protein (5\% increase in consumption of protein derived from meat and meat products) was shown to be associated with a $34 \%$ increased risk of T2D, whereas the intake of plant protein was shown to have a considerable protective effect in 1190 elderly participants from the Mediterranean islands [17]. A large study of 92,088 women and 40,722 men from the United States found that substituting $5 \%$ of energy intake from animal protein with plant protein was associated with a decrease in T2D risk by $23 \%$ [69]. Moreover, a systematic review and meta-analysis of thirteen randomised controlled trials $(n=280$ middle-aged adults from Iran, Denmark, United States, Germany, Canada and Greece) found significant decreases in $\mathrm{HbA1c}$, fasting insulin and fasting glucose in diets that substituted animal protein with plant protein at a median level of $\sim 35 \%$ of total protein intake/day [70]. Another systematic review and meta-analysis of eleven cohort studies, including individuals from the United States, Europe, Asia, Melbourne and Finland (52,637 cases among 483,174 individuals), showed that the intakes of total protein and animal protein increased T2D risk in both men and women, whereas plant protein intake decreased T2D risk in women [71]. Previous cohort studies in the United States (90,239 women and 40,539 men) and in the Netherlands (6798 individuals) found that an association between the higher adherence to a plant- 
based diet and a lower risk of T2D [72,73]. In contrast, other prospective cohort studies ( $n=8370-38,094$ individuals) observed no significant associations [13,74,75]. It is possible that the interactions between genetic factors and protein intake might be one of the reasons for the discrepancies in the effect of dietary protein intake on the risk of T2D and its related traits.

The dietary patterns across different parts of India have been significantly affected by urbanisation. Given that food availability and purchasing power are higher in urban than rural areas, diets of both residents tend to differ significantly [12,76]. Protein intake has been shown to be positively related to an individual's income, where the demand for animal protein increased with the disposable income [12]. Higher protein intake has also been reported in urban areas in India, with the overall mean intake of protein being the highest in the high-income group (73.1 g/day) followed by the middle-income group (63.2 g/day), industrial labourer $(59.4 \mathrm{~g} /$ day) and low-income group $(57.8 \mathrm{~g} /$ day) $[77,78]$. The present study included urban residents and the mean protein intake is $71.6 \pm 22.7 \mathrm{~g} /$ day, which is higher than dietary protein recommendations for Asian Indians (55-60 g/day) [79]. However, the mean protein intake is only $11 \%$ (percentage calories coming from the protein), which is similar to the previous large studies, such as the National Family Health and National Nutrition Monitoring Bureau surveys that were conducted in the Indian population [80,81]. A study in 6907 adults from South India aged $>20$ years showed that the consumption of pulses was lower in rural compared to urban Indian adults [82] and a cross-sectional study including 56,742 men and 99,574 women aged 20-49 years also demonstrated that inverse association between daily or weekly legumes and the presence of diabetes [83]. A recent study in 1033 Indian adults also showed that a significant decrease in the risk of T2D was observed among those having higher intakes of legumes and pulses [84]. In the same population, a study in 2042 individuals reported that pulses and legumes contributed to only $17.2 \%$ of the daily protein suggesting a reduced intake of plant protein [85]. Hence, according to the findings from the previous studies and the GRS-plant protein intake interaction from the present study, increasing the intake of plant protein might be an effective strategy to arrest the rising epidemic of T2D among Indian adults.

The strength of this study is the use of a representative sample of the urban Chennai population. Given that diabetes prevalence continues to be higher in urban residents compared to rural residents in India [2,86,87], understanding gene-diet interactions on T2D in urban areas would improve diabetes prevention strategies among urban Indians. Our study used unweighted GRSs to analyse the combined effect of several SNPs, which is an effective approach to study polygenic diseases such as T2D and obesity, providing a better knowledge of disease risk compared to a single-SNP analysis [36]. A comprehensive and validated semi-quantitative FFQ was used for analysing dietary intakes [48]. Furthermore, anthropometric outcomes were assessed by qualified staff rather than self-reported to improve the accuracy of anthropometric measurements. However, the study has several limitations. First, the study has a small sample size suggesting that we might have had insufficient power for our analysis. To maximise power, we used a GRS approach, which has an advantage over single-SNP analysis, and significant associations and interactions were found. Second, the observational nature of the study design cannot explain causal relationships or exclude residual confounding; however, sensitivity analyses were carried out where adjustment was performed for additional confounding factors such as diabetes duration, total fat intake, physical activity level, anti-diabetic medication, alcohol consumption, smoking and fibre intake. Third, dietary intake was assessed using self-reported FFQ, which might have introduced recall and measurement bias. Finally, SNPs contributing to our GRSs represent only a small proportion of the increasing number of identified metabolic disease-associated variants in Asian Indians; however, we have chosen SNPs in TCF7L2 and FTO genes that have presented the most consistent and strongest associations with T2D and obesity, respectively, in several populations [32,88]. 


\section{Conclusions}

In summary, the current study has found a novel GRS-protein intake interaction where individuals with $>1$ risk allele and lower intake of plant protein $(<39 \mathrm{~g} /$ day $)$ had higher FPG and HbA1c levels. This suggests that increasing the intake of plant protein may be an effective approach to overcome the genetic risk of diabetes in urban Asian Indians. To prove this hypothesis, appropriate randomised clinical trials with diets of higher and lower plant protein intake need to be performed. Moreover, there is a need for studies with larger sample sizes to confirm gene-diet interactions. Ultimately, there is a need for the assessment of the clinical benefit of targeted interventions based on an individual's underlying genetic risk.

Supplementary Materials: The following are available online at https:/ /www.mdpi.com/article/10 $.3390 /$ nu13093064/s1, Table S1: Genotype distribution of the seven SNPs that were chosen for our study $(n=1062)$, Figure S1: Methodology of the Chennai Urban Rural Epidemiology Study (CURES), Figure S2: Interaction between 3-SNP GRS and animal protein intake (\%) on fasting plasma glucose and glycated haemoglobin after adjusting for anti-diabetic medication.

Author Contributions: Conceptualisation, K.S.V.; methodology, K.S.V., V.S., R.G. and S.A.; software, S.A. and R.G.; validation, K.S.V. and S.A.; formal analysis, S.A.; investigation, D.B.; resources, V.S., R.P. and J.A.L.; data curation, V.S., R.P. and D.B.; writing—original draft preparation, S.A. and K.S.V.; writing - review and editing, S.A., R.G., C.S.S.R., V.S., R.M.A., R.P., J.A.L., V.M., V.R. and K.S.V.; visualisation, V.M. and K.S.V.; supervision, V.M., V.R., J.A.L. and K.S.V.; project administration, V.M., V.R. and K.S.V.; funding acquisition, V.M., V.R. and K.S.V. All authors have read, edited, and approved the published version of the manuscript.

Funding: This research received no external funding.

Acknowledgments: We thank all the participants from CURES for their cooperation. The Chennai Willingdon Corporate Foundation supported the CURES field studies, and this is the 160th paper from CURES (CURES-160). Karani S. Vimaleswaran acknowledges support from the Ministry of Higher Education of Saudi Arabia for the scholarship given to Sooad Alsulami. We thank Ramya Kandasamy for her technical assistance with the genotyping analysis.

Conflicts of Interest: The authors declare no conflict of interest.

\section{References}

1. Khan, N.A.; Wang, H.; Anand, S.; Jin, Y.; Campbell, N.R.; Pilote, L.; Quan, H. Ethnicity and sex affect diabetes incidence and outcomes. Diabetes Care 2011, 34, 96-101. [CrossRef]

2. Mohan, V.; Mathur, P.; Deepa, R.; Deepa, M.; Shukla, D.K.; Menon, G.R.; Anand, K.; Desai, N.G.; Joshi, P.P.; Mahanta, J.; et al. Urban rural differences in prevalence of self-reported diabetes in India-The WHO-ICMR Indian NCD risk factor surveillance. Diabetes Res. Clin. Pract. 2008, 80, 159-168. [CrossRef] [PubMed]

3. Chan, J.C.; Malik, V.; Jia, W.; Kadowaki, T.; Yajnik, C.S.; Yoon, K.H.; Hu, F.B. Diabetes in Asia: Epidemiology, risk factors, and pathophysiology. JAMA 2009, 301, 2129-2140. [CrossRef] [PubMed]

4. Mohan, V. Why are Indians more prone to diabetes? J. Assoc. Physicians India 2004, 52, 468-474.

5. Ramachandran, A.; Ma, R.C.; Snehalatha, C. Diabetes in Asia. Lancet 2010, 375, 408-418. [CrossRef]

6. Diabetes Atlas 9th Edition. Available online: https:/ / www.diabetesatlas.org/en/ (accessed on 16 January 2021).

7. Tandon, N.; Anjana, R.M.; Mohan, V.; Kaur, T.; Afshin, A.; Ong, K.; Mukhopadhyay, S.; Thomas, N.; Bhatia, E.; Krishnan, A.; et al. The increasing burden of diabetes and variations among the states of India: The Global Burden of Disease Study 1990-2016. Lancet Glob. Health 2018, 6, e1352-e1362. [CrossRef]

8. Bodhini, D.; Gaal, S.; Shatwan, I.; Ramya, K.; Ellahi, B.; Surendran, S.; Sudha, V.; Anjana, M.R.; Mohan, V.; Lovegrove, J.A.; et al. Interaction between TCF7L2 polymorphism and dietary fat intake on high density lipoprotein cholesterol. PLoS ONE 2017, 12, e0188382. [CrossRef] [PubMed]

9. Vimaleswaran, K.S.; Bodhini, D.; Lakshmipriya, N.; Ramya, K.; Anjana, R.M.; Sudha, V.; Lovegrove, J.A.; Kinra, S.; Mohan, V.; Radha, V. Erratum to: Interaction between FTO gene variants and lifestyle factors on metabolic traits in an Asian Indian population. Nutr. Metab. 2016, 13, 41. [CrossRef]

10. Gassasse, Z.; Smith, D.; Finer, S.; Gallo, V. Association between urbanisation and type 2 diabetes: An ecological study. BMJ Glob. Health 2017, 2, e000473. [CrossRef]

11. Ramachandran, A.; Snehalatha, C.; Latha, E.; Manoharan, M.; Vijay, V. Impacts of urbanisation on the lifestyle and on the prevalence of diabetes in native Asian Indian population. Diabetes Res. Clin. Pract. 1999, 44, 207-213. [CrossRef] 
12. Rampal, P. An Analysis of Protein Consumption in India Through Plant and Animal Sources. Food Nutr. Bull. 2018, 39, 564-580. [CrossRef] [PubMed]

13. Sluijs, I.; Beulens, J.W.; van der, A.D.; Spijkerman, A.M.; Grobbee, D.E.; van der Schouw, Y.T. Dietary intake of total, animal, and vegetable protein and risk of type 2 diabetes in the European Prospective Investigation into Cancer and Nutrition (EPIC)-NL study. Diabetes Care 2010, 33, 43-48. [CrossRef]

14. Song, Y.; Manson, J.E.; Buring, J.E.; Liu, S. A prospective study of red meat consumption and type 2 diabetes in middle-aged and elderly women: The women's health study. Diabetes Care 2004, 27, 2108-2115. [CrossRef]

15. Ericson, U.; Sonestedt, E.; Gullberg, B.; Hellstrand, S.; Hindy, G.; Wirfält, E.; Orho-Melander, M. High intakes of protein and processed meat associate with increased incidence of type 2 diabetes. Br. J. Nutr. 2013, 109, 1143-1153. [CrossRef] [PubMed]

16. van Nielen, M.; Feskens, E.J.; Mensink, M.; Sluijs, I.; Molina, E.; Amiano, P.; Ardanaz, E.; Balkau, B.; Beulens, J.W.; Boeing, H.; et al. Dietary protein intake and incidence of type 2 diabetes in Europe: The EPIC-InterAct Case-Cohort Study. Diabetes Care 2014, 37, 1854-1862. [CrossRef]

17. Pounis, G.D.; Tyrovolas, S.; Antonopoulou, M.; Zeimbekis, A.; Anastasiou, F.; Bountztiouka, V.; Metallinos, G.; Gotsis, E.; Lioliou, E.; Polychronopoulos, E.; et al. Long-term animal-protein consumption is associated with an increased prevalence of diabetes among the elderly: The Mediterranean Islands (MEDIS) study. Diabetes Metab. 2010, 36, 484-490. [CrossRef] [PubMed]

18. Abdullah, N.; Attia, J.; Oldmeadow, C.; Scott, R.J.; Holliday, E.G. The architecture of risk for type 2 diabetes: Understanding Asia in the context of global findings. Int. J. Endocrinol. 2014, 2014, 593982. [CrossRef]

19. Raj, S.M.; Pei, A.; Foll, M.; Schlamp, F.; Excoffier, L.; Fuller, D.Q.; Kivisild, T.; Clark, A.G. Reconstruction of nine thousand years of agriculture-based diet and impact on human genetic diversity in Asia. bioRxiv 2019, 747709. [CrossRef]

20. Sanghera, D.K.; Ortega, L.; Han, S.; Singh, J.; Ralhan, S.K.; Wander, G.S.; Mehra, N.K.; Mulvihill, J.J.; Ferrell, R.E.; Nath, S.K.; et al. Impact of nine common type 2 diabetes risk polymorphisms in Asian Indian Sikhs: PPARG2 (Pro12Ala), IGF2BP2, TCF7L2 and FTO variants confer a significant risk. BMC Med. Genet. 2008, 9, 59. [CrossRef]

21. Chauhan, G.; Tabassum, R.; Mahajan, A.; Dwivedi, O.P.; Mahendran, Y.; Kaur, I.; Nigam, S.; Dubey, H.; Varma, B.; Madhu, S.V.; et al. Common variants of FTO and the risk of obesity and type 2 diabetes in Indians. J. Hum. Genet. 2011, 56, 720-726. [CrossRef]

22. Ramya, K.; Radha, V.; Ghosh, S.; Majumder, P.P.; Mohan, V. Genetic variations in the FTO gene are associated with type 2 diabetes and obesity in south Indians (CURES-79). Diabetes Technol. Ther. 2011, 13, 33-42. [CrossRef] [PubMed]

23. Yajnik, C.S.; Janipalli, C.S.; Bhaskar, S.; Kulkarni, S.R.; Freathy, R.M.; Prakash, S.; Mani, K.R.; Weedon, M.N.; Kale, S.D.; Deshpande, J.; et al. FTO gene variants are strongly associated with type 2 diabetes in South Asian Indians. Diabetologia 2009, 52, $247-252$. [CrossRef] [PubMed]

24. Kooner, J.S.; Saleheen, D.; Sim, X.; Sehmi, J.; Zhang, W.; Frossard, P.; Been, L.F.; Chia, K.S.; Dimas, A.S.; Hassanali, N.; et al. Genome-wide association study in individuals of South Asian ancestry identifies six new type 2 diabetes susceptibility loci. Nat. Genet. 2011, 43, 984-989. [CrossRef] [PubMed]

25. Chauhan, G.; Spurgeon, C.J.; Tabassum, R.; Bhaskar, S.; Kulkarni, S.R.; Mahajan, A.; Chavali, S.; Kumar, M.V.; Prakash, S.; Dwivedi, O.P.; et al. Impact of common variants of PPARG, KCNJ11, TCF7L2, SLC30A8, HHEX, CDKN2A, IGF2BP2, and CDKAL1 on the risk of type 2 diabetes in 5164 Indians. Diabetes 2010, 59, 2068-2074. [CrossRef] [PubMed]

26. Rees, S.D.; Hydrie, M.Z.; Shera, A.S.; Kumar, S.; O’Hare, J.P.; Barnett, A.H.; Basit, A.; Kelly, M.A. Replication of 13 genome-wide association (GWA)-validated risk variants for type 2 diabetes in Pakistani populations. Diabetologia 2011, 54, 1368-1374. [CrossRef]

27. Humphries, S.E.; Gable, D.; Cooper, J.A.; Ireland, H.; Stephens, J.W.; Hurel, S.J.; Li, K.W.; Palmen, J.; Miller, M.A.; Cappuccio, F.P.; et al. Common variants in the TCF7L2 gene and predisposition to type 2 diabetes in UK European Whites, Indian Asians and Afro-Caribbean men and women. J. Mol. Med. 2006, 84, 1005-1014. [CrossRef] [PubMed]

28. Vasan, S.K.; Karpe, F.; Gu, H.F.; Brismar, K.; Fall, C.H.; Ingelsson, E.; Fall, T. FTO genetic variants and risk of obesity and type 2 diabetes: A meta-analysis of 28,394 Indians. Obesity 2014, 22, 964-970. [CrossRef]

29. Chandak, G.R.; Janipalli, C.S.; Bhaskar, S.; Kulkarni, S.R.; Mohankrishna, P.; Hattersley, A.T.; Frayling, T.M.; Yajnik, C.S. Common variants in the TCF7L2 gene are strongly associated with type 2 diabetes mellitus in the Indian population. Diabetologia 2007, 50, 63-67. [CrossRef]

30. Bodhini, D.; Radha, V.; Dhar, M.; Narayani, N.; Mohan, V. The rs12255372(G/T) and rs7903146(C/T) polymorphisms of the TCF7L2 gene are associated with type 2 diabetes mellitus in Asian Indians. Metabolism 2007, 56, 1174-1178. [CrossRef]

31. Tong, Y.; Lin, Y.; Zhang, Y.; Yang, J.; Zhang, Y.; Liu, H.; Zhang, B. Association between TCF7L2 gene polymorphisms and susceptibility to type 2 diabetes mellitus: A large Human Genome Epidemiology (HuGE) review and meta-analysis. BMC Med. Genet. 2009, 10, 15. [CrossRef]

32. Fuchsberger, C.; Flannick, J.; Teslovich, T.M.; Mahajan, A.; Agarwala, V.; Gaulton, K.J.; Ma, C.; Fontanillas, P.; Moutsianas, L.; McCarthy, D.J.; et al. The genetic architecture of type 2 diabetes. Nature 2016, 536, 41-47. [CrossRef]

33. Morris, A.P.; Voight, B.F.; Teslovich, T.M.; Ferreira, T.; Segrè, A.V.; Steinthorsdottir, V.; Strawbridge, R.J.; Khan, H.; Grallert, H.; Mahajan, A.; et al. Large-scale association analysis provides insights into the genetic architecture and pathophysiology of type 2 diabetes. Nat. Genet. 2012, 44, 981-990. [PubMed]

34. Scott, R.A.; Scott, L.J.; Mägi, R.; Marullo, L.; Gaulton, K.J.; Kaakinen, M.; Pervjakova, N.; Pers, T.H.; Johnson, A.D.; Eicher, J.D.; et al. An Expanded Genome-Wide Association Study of Type 2 Diabetes in Europeans. Diabetes 2017, 66, 2888-2902. [CrossRef] [PubMed] 
35. Mahajan, A.; Taliun, D.; Thurner, M.; Robertson, N.R.; Torres, J.M.; Rayner, N.W.; Payne, A.J.; Steinthorsdottir, V.; Scott, R.A.; Grarup, N.; et al. Fine-mapping type 2 diabetes loci to single-variant resolution using high-density imputation and islet-specific epigenome maps. Nat. Genet. 2018, 50, 1505-1513. [CrossRef] [PubMed]

36. Udler, M.S.; McCarthy, M.I.; Florez, J.C.; Mahajan, A. Genetic Risk Scores for Diabetes Diagnosis and Precision Medicine. Endocr. Rev. 2019, 40, 1500-1520. [CrossRef]

37. Manolio, T.A.; Collins, F.S.; Cox, N.J.; Goldstein, D.B.; Hindorff, L.A.; Hunter, D.J.; McCarthy, M.I.; Ramos, E.M.; Cardon, L.R.; Chakravarti, A.; et al. Finding the missing heritability of complex diseases. Nature 2009, 461, 747-753. [CrossRef]

38. Ordovas, J.M.; Ferguson, L.R.; Tai, E.S.; Mathers, J.C. Personalised nutrition and health. Bmj 2018, 361, bmj-k2173. [CrossRef] [PubMed]

39. Dietrich, S.; Jacobs, S.; Zheng, J.S.; Meidtner, K.; Schwingshackl, L.; Schulze, M.B. Gene-lifestyle interaction on risk of type 2 diabetes: A systematic review. Obes. Rev. 2019, 20, 1557-1571. [CrossRef]

40. Wang, T.; Huang, T.; Zheng, Y.; Rood, J.; Bray, G.A.; Sacks, F.M.; Qi, L. Genetic variation of fasting glucose and changes in glycemia in response to 2-year weight-loss diet intervention: The POUNDS LOST trial. Int. J. Obes. 2016, 40, 1164-1169. [CrossRef]

41. Eriksen, R.; Gibson, R.; Aresu, M.; Heard, A.; Chan, Q.; Evangelou, E.; Gao, H.; Elliott, P.; Frost, G. Gene-diet quality interactions on haemoglobin A1c and type 2 diabetes risk: The Airwave Health Monitoring Study. Endocrinol. Diabetes Metab. 2019, 2, e00074. [CrossRef]

42. Kim, D.S.; Kim, B.C.; Daily, J.W.; Park, S. High genetic risk scores for impaired insulin secretory capacity doubles the risk for type 2 diabetes in Asians and is exacerbated by Western-type diets. Diabetes Metab. Res. Rev. 2018, 34, e2944. [CrossRef]

43. Qi, L.; Cornelis, M.C.; Zhang, C.; van Dam, R.M.; Hu, F.B. Genetic predisposition, Western dietary pattern, and the risk of type 2 diabetes in men. Am. J. Clin. Nutr. 2009, 89, 1453-1458. [CrossRef] [PubMed]

44. Zheng, J.S.; Li, K.; Huang, T.; Chen, Y.; Xie, H.; Xu, D.; Sun, J.; Li, D. Genetic Risk Score of Nine Type 2 Diabetes Risk Variants that Interact with Erythrocyte Phospholipid Alpha-Linolenic Acid for Type 2 Diabetes in Chinese Hans: A Case-Control Study. Nutrients 2017, 9, 376. [CrossRef] [PubMed]

45. Deepa, M.; Pradeepa, R.; Rema, M.; Mohan, A.; Deepa, R.; Shanthirani, S.; Mohan, V. The Chennai Urban Rural Epidemiology Study (CURES)-study design and methodology (urban component) (CURES-I). J. Assoc. Physicians India 2003, 51, 863-870.

46. Alberti, K.G.; Zimmet, P.Z. Definition, diagnosis and classification of diabetes mellitus and its complications. Part 1: Diagnosis and classification of diabetes mellitus provisional report of a WHO consultation. Diabet. Med. 1998, 15, 539-553. [CrossRef]

47. Regional Office for the Western Pacific. The Asia-Pacific Perspective. Redefining Obesity and Its Treatment. Sydney: Health Communications Australia. Available online: https:/ /apps.who.int/iris/handle/10665/206936 (accessed on 5 June 2021).

48. Sudha, V.; Radhika, G.; Sathya, R.M.; Ganesan, A.; Mohan, V. Reproducibility and validity of an interviewer-administered semi-quantitative food frequency questionnaire to assess dietary intake of urban adults in southern India. Int. J. Food Sci. Nutr. 2006, 57, 481-493. [CrossRef]

49. Fretts, A.M.; Follis, J.L.; Nettleton, J.A.; Lemaitre, R.N.; Ngwa, J.S.; Wojczynski, M.K.; Kalafati, I.P.; Varga, T.V.; Frazier-Wood, A.C.; Houston, D.K.; et al. Consumption of meat is associated with higher fasting glucose and insulin concentrations regardless of glucose and insulin genetic risk scores: A meta-analysis of 50,345 Caucasians. Am. J. Clin. Nutr. 2015, 102, 1266-1278. [CrossRef] [PubMed]

50. Li, H.; Khor, C.C.; Fan, J.; Lv, J.; Yu, C.; Guo, Y.; Bian, Z.; Yang, L.; Millwood, I.Y.; Walters, R.G.; et al. Genetic risk, adherence to a healthy lifestyle, and type 2 diabetes risk among 550,000 Chinese adults: Results from 2 independent Asian cohorts. Am. J. Clin. Nutr. 2020, 111, 698-707. [CrossRef]

51. Scuteri, A.; Sanna, S.; Chen, W.M.; Uda, M.; Albai, G.; Strait, J.; Najjar, S.; Nagaraja, R.; Orru, M.; Usala, G.; et al. Genome-wide association scan shows genetic variants in the FTO gene are associated with obesity-related traits. PLoS Genet. 2007, 3, e115. [CrossRef]

52. Liu, Y.; Liu, Z.; Song, Y.; Zhou, D.; Zhang, D.; Zhao, T.; Chen, Z.; Yu, L.; Yang, Y.; Feng, G.; et al. Meta-analysis added power to identify variants in FTO associated with type 2 diabetes and obesity in the Asian population. Obesity 2010, 18, 1619-1624. [CrossRef] [PubMed]

53. Peng, S.; Zhu, Y.; Lü, B.; Xu, F.; Li, X.; Lai, M. TCF7L2 gene polymorphisms and type 2 diabetes risk: A comprehensive and updated meta-analysis involving 121,174 subjects. Mutagenesis 2013, 28, 25-37. [CrossRef]

54. Tönjes, A.; Zeggini, E.; Kovacs, P.; Böttcher, Y.; Schleinitz, D.; Dietrich, K.; Morris, A.P.; Enigk, B.; Rayner, N.W.; Koriath, M.; et al. Association of FTO variants with BMI and fat mass in the self-contained population of Sorbs in Germany. Eur. J. Hum. Genet. EJHG 2010, 18, 104-110. [CrossRef]

55. Prabhakaran, D.; Jeemon, P.; Sharma, M.; Roth, G.A.; Johnson, C.; Harikrishnan, S.; Gupta, R.; Pandian, J.D.; Naik, N.; Roy, A. The changing patterns of cardiovascular diseases and their risk factors in the states of India: The Global Burden of Disease Study 1990-2016. Lancet Glob. Health 2018, 6, e1339-e1351. [CrossRef]

56. Gupta, V.; Vinay, D.G.; Sovio, U.; Rafiq, S.; Kranthi Kumar, M.V.; Janipalli, C.S.; Evans, D.; Mani, K.R.; Sandeep, M.N.; Taylor, A.; et al. Association study of 25 type 2 diabetes related Loci with measures of obesity in Indian sib pairs. PLoS ONE 2013, 8, e53944.

57. Wheeler, E.; Leong, A.; Liu, C.T.; Hivert, M.F.; Strawbridge, R.J.; Podmore, C.; Li, M.; Yao, J.; Sim, X.; Hong, J.; et al. Impact of common genetic determinants of Hemoglobin A1c on type 2 diabetes risk and diagnosis in ancestrally diverse populations: A transethnic genome-wide meta-analysis. PLoS Med. 2017, 14, e1002383. [CrossRef] [PubMed] 
58. Janipalli, C.S.; Kumar, M.V.; Vinay, D.G.; Sandeep, M.N.; Bhaskar, S.; Kulkarni, S.R.; Aruna, M.; Joglekar, C.V.; Priyadharshini, S.; Maheshwari, N.; et al. Analysis of 32 common susceptibility genetic variants and their combined effect in predicting risk of Type 2 diabetes and related traits in Indians. Diabet. Med. 2012, 29, 121-127. [CrossRef]

59. Anand, S.S.; Meyre, D.; Pare, G.; Bailey, S.D.; Xie, C.; Zhang, X.; Montpetit, A.; Desai, D.; Bosch, J.; Mohan, V.; et al. Genetic information and the prediction of incident type 2 diabetes in a high-risk multiethnic population: The EpiDREAM genetic study. Diabetes Care 2013, 36, 2836-2842. [CrossRef]

60. Alsulami, S.; Aji, A.S.; Ariyasra, U.; Sari, S.R.; Tasrif, N.; Yani, F.F.; Lovegrove, J.A.; Sudji, I.R.; Lipoeto, N.I.; Vimaleswaran, K.S. Interaction between the genetic risk score and dietary protein intake on cardiometabolic traits in Southeast Asian. Genes Nutr. 2020, 15, 19. [CrossRef]

61. Czajkowski, P.; Adamska-Patruno, E.; Bauer, W.; Fiedorczuk, J.; Krasowska, U.; Moroz, M.; Gorska, M.; Kretowski, A. The Impact of FTO Genetic Variants on Obesity and Its Metabolic Consequences is Dependent on Daily Macronutrient Intake. Nutrients 2020, 12, 3255. [CrossRef]

62. Li, S.X.; Imamura, F.; Schulze, M.B.; Zheng, J.; Ye, Z.; Agudo, A.; Ardanaz, E.; Aune, D.; Boeing, H.; Dorronsoro, M.; et al. Interplay between genetic predisposition, macronutrient intake and type 2 diabetes incidence: Analysis within EPIC-InterAct across eight European countries. Diabetologia 2018, 61, 1325-1332. [CrossRef]

63. Shobana, R.; Snehalatha, C.; Latha, E.; Vijay, V.; Ramachandran, A. Dietary profile of urban south Indians and its relations with glycaemic status. Diabetes Res. Clin. Pract. 1998, 42, 181-186. [CrossRef]

64. Joshi, S.R.; Bhansali, A.; Bajaj, S.; Banzal, S.S.; Dharmalingam, M.; Gupta, S.; Mukhopadhyay, S.; Shah, P.R.; Sahay, R.; Sarkar, S.; et al. Results from a dietary survey in an Indian T2DM population: A STARCH study. BMJ Open 2014, 4, e005138. [CrossRef] [PubMed]

65. Wang, E.T.; de Koning, L.; Kanaya, A.M. Higher protein intake is associated with diabetes risk in South Asian Indians: The Metabolic Syndrome and Atherosclerosis in South Asians Living in America (MASALA) study. J. Am. Coll. Nutr. 2010, 29, 130-135. [CrossRef]

66. Dong, J.Y.; Zhang, Z.L.; Wang, P.Y.; Qin, L.Q. Effects of high-protein diets on body weight, glycaemic control, blood lipids and blood pressure in type 2 diabetes: Meta-analysis of randomised controlled trials. Br. J. Nutr. 2013, 110, 781-789. [CrossRef]

67. Hession, M.; Rolland, C.; Kulkarni, U.; Wise, A.; Broom, J. Systematic review of randomized controlled trials of low-carbohydrate vs. low-fat/low-calorie diets in the management of obesity and its comorbidities. Obes. Rev. 2009, 10, 36-50. [CrossRef] [PubMed]

68. Santesso, N.; Akl, E.A.; Bianchi, M.; Mente, A.; Mustafa, R.; Heels-Ansdell, D.; Schünemann, H.J. Effects of higher- versus lower-protein diets on health outcomes: A systematic review and meta-analysis. Eur. J. Clin. Nutr. 2012, 66, 780-788. [CrossRef]

69. Malik, V.S.; Li, Y.; Tobias, D.K.; Pan, A.; Hu, F.B. Dietary Protein Intake and Risk of Type 2 Diabetes in US Men and Women. Am. J. Epidemiol. 2016, 183, 715-728. [CrossRef]

70. Viguiliouk, E.; Stewart, S.E.; Jayalath, V.H.; Ng, A.P.; Mirrahimi, A.; de Souza, R.J.; Hanley, A.J.; Bazinet, R.P.; Blanco Mejia, S.; Leiter, L.A.; et al. Effect of Replacing Animal Protein with Plant Protein on Glycemic Control in Diabetes: A Systematic Review and Meta-Analysis of Randomized Controlled Trials. Nutrients 2015, 7, 9804-9824. [CrossRef]

71. Tian, S.; Xu, Q.; Jiang, R.; Han, T.; Sun, C.; Na, L. Dietary Protein Consumption and the Risk of Type 2 Diabetes: A Systematic Review and Meta-Analysis of Cohort Studies. Nutrients 2017, 9, 982.

72. Satija, A.; Bhupathiraju, S.N.; Rimm, E.B.; Spiegelman, D.; Chiuve, S.E.; Borgi, L.; Willett, W.C.; Manson, J.E.; Sun, Q.; Hu, F.B. Plant-Based Dietary Patterns and Incidence of Type 2 Diabetes in US Men and Women: Results from Three Prospective Cohort Studies. PLoS Med. 2016, 13, e1002039. [CrossRef]

73. Chen, Z.; Zuurmond, M.G.; van der Schaft, N.; Nano, J.; Wijnhoven, H.A.H.; Ikram, M.A.; Franco, O.H.; Voortman, T. Plant versus animal based diets and insulin resistance, prediabetes and type 2 diabetes: The Rotterdam Study. Eur. J. Epidemiol. 2018, 33, 883-893. [CrossRef]

74. Alhazmi, A.; Stojanovski, E.; McEvoy, M.; Garg, M.L. Macronutrient intake and type 2 diabetes risk in middle-aged Australian women. Results from the Australian Longitudinal Study on Women's Health. Public Health Nutr. 2014, 17, 1587-1594. [CrossRef]

75. Nanri, A.; Mizoue, T.; Kurotani, K.; Goto, A.; Oba, S.; Noda, M.; Sawada, N.; Tsugane, S. Low-carbohydrate diet and type 2 diabetes risk in Japanese men and women: The Japan Public Health Center-Based Prospective Study. PLoS ONE 2015, 10, e0118377. [CrossRef] [PubMed]

76. Kumar, P.; Mathur, V. Structural changes in demand for food in India. J. Agric. Econ. 1996, 51, 664-673.

77. National Nutrition Monitoring Bureau (1984) Report on Urban Population (1975-1980). Available online: https:/ /www.nin.res. in/downloads/Report_Of_Urban_Population_75-80.pdf (accessed on 16 April 2021).

78. Swaminathan, S.; Vaz, M.; Kurpad, A.V. Protein intakes in India. Br. J. Nutr. 2012, 108, S50-S58. [CrossRef] [PubMed]

79. Indian Council of Medical Research (ICMR). Dietary Guidelines for Indians. Available online: https://www.nin.res.in/ downloads / DietaryGuidelinesforNINwebsite.pdf (accessed on 5 June 2021).

80. National Family Health Survey (NFHS-4). International Institute of Population Science (IIPS). Available online: http://rchiips. $\mathrm{org} / \mathrm{nfhs} /$ factsheet_nfhs-4.shtml (accessed on 5 June 2021).

81. Indian Council of Social Science Research (ICSSR). Available online: http:/ /www.icssrdataservice.in/datarepository/index.php/ catalog/91 (accessed on 5 June 2021). 
82. Sowmya, N.; Lakshmipriya, N.; Arumugam, K.; Venkatachalam, S.; Vijayalakshmi, P.; Ruchi, V.; Geetha, G.; Anjana, R.M.; Mohan, V.; Krishnaswamy, K.; et al. Comparison of dietary profile of a rural south Indian population with the current dietary recommendations for prevention of non-communicable diseases (CURES 147). Indian J. Med Res. 2016, 144, 112-119. [PubMed]

83. Agrawal, S.; Ebrahim, S. Association between legume intake and self-reported diabetes among adult men and women in India. BMC Public Health 2013, 13, 706. [CrossRef]

84. Lakshmi Priya, N.; Gayathri, R.; Sudha, V.; Geetha, G.; Gayathri, N.; Shilpa, B.; Shanthi Rani, C.; Kamala, K.; Anjana, R.; Ranjit, U.; et al. Prospective associations between a food-based Indian Diet Quality Score and type 2 diabetes risk among South Indian adults (CURES-154). J. Diabetol. 2020, 11, 115-124.

85. Radhika, G.; Sathya, R.M.; Ganesan, A.; Saroja, R.; Vijayalakshmi, P.; Sudha, V.; Mohan, V. Dietary profile of urban adult population in South India in the context of chronic disease epidemiology (CURES-68). Public Health Nutr. 2011, 14, 591-598. [CrossRef]

86. Anjana, R.M.; Deepa, M.; Pradeepa, R.; Mahanta, J.; Narain, K.; Das, H.K.; Adhikari, P.; Rao, P.V.; Saboo, B.; Kumar, A.; et al. Prevalence of diabetes and prediabetes in 15 states of India: Results from the ICMR-INDIAB population-based cross-sectional study. Lancet Diabetes Endocrinol. 2017, 5, 585-596. [CrossRef]

87. Deepa, M.; Anjana, R.M.; Manjula, D.; Narayan, K.M.; Mohan, V. Convergence of prevalence rates of diabetes and cardiometabolic risk factors in middle and low income groups in urban India: 10-year follow-up of the Chennai Urban Population Study. J. Diabetes Sci. Technol. 2011, 5, 918-927. [CrossRef] [PubMed]

88. Goodarzi, M.O. Genetics of obesity: What genetic association studies have taught us about the biology of obesity and its complications. Lancet Diabetes Endocrinol. 2018, 6, 223-236. [CrossRef] 